\title{
Necrotizing Soft Tissue Infections
}

\author{
Chance Witt, MD, Sharmila Dissanaike, MD
}

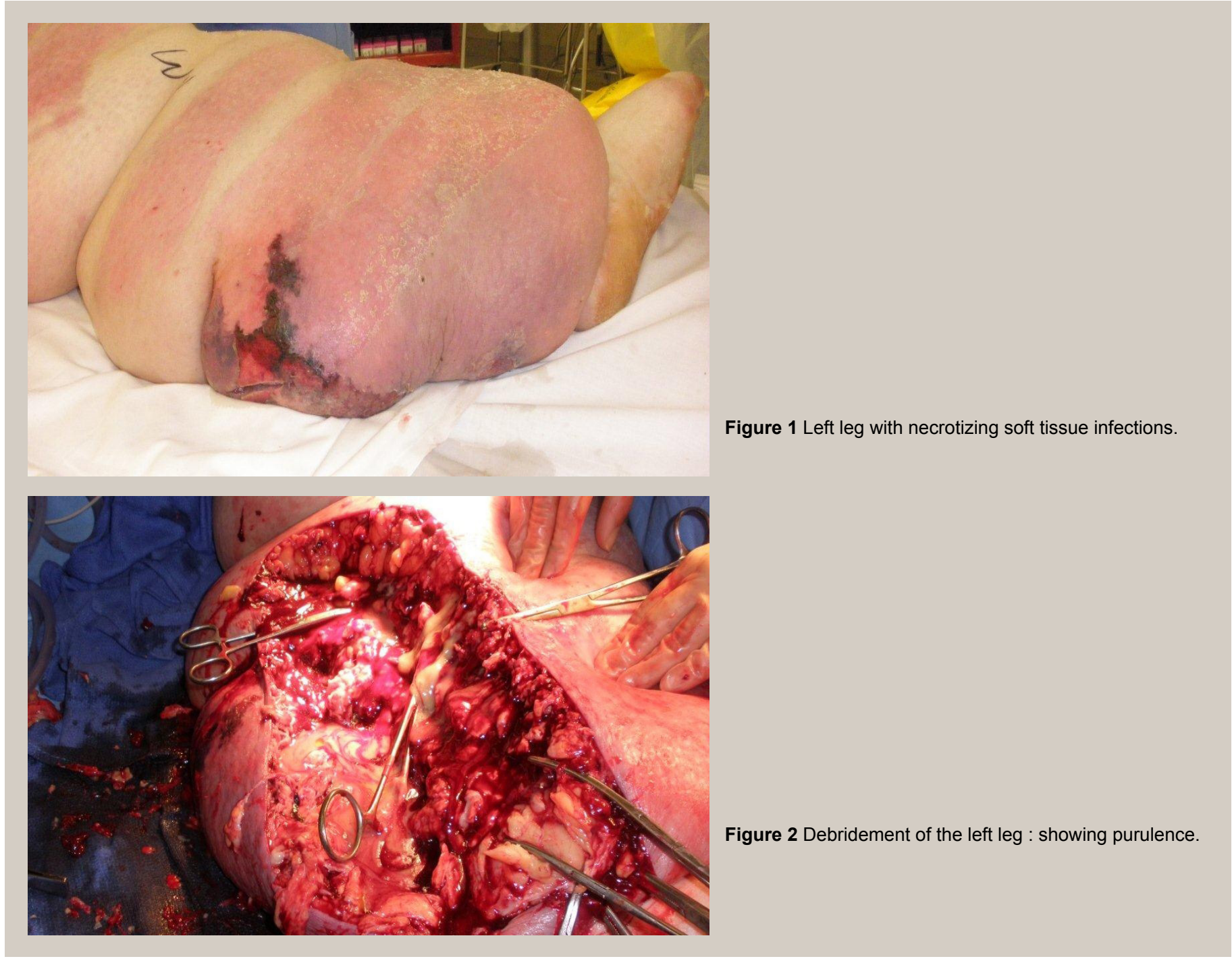

Author Affiliation: Chance Witt, MD, is a resident in General Surgery at the Mayo School of Graduate Medical Education in Rochester, MN. Sharmila Dissanaike, MD, is a trauma and burn surgeon in the Department of Surgery at TTUHSC in Lubbock, TX. Received: 9/16/2012

Accepted: $12 / 19 / 2012$

Reviewers: Kenneth Nugent, MD; Richard Winn, MD

DOI: 10.12746/swrccc2013.0101.009
This is a very heavy woman who initially had an Necrotizing Soft Tissue Infection (NSTI) of the right leg which was extensively debrided and skin grafted and healed well, then presented 2 months later with a new NSTI of the left leg.

\section{References}

1. Wong $\mathrm{CH}$, Chang $\mathrm{HC}$, Pasupathy $\mathrm{S}$, et al. Necrotizing fasciitis: clinical presentation, microbiology, and determinants of mortality. J Bone Joint Surg Am 2003; 85:1454-60. 